\begin{tabular}{|c|c|c|}
\hline $\begin{array}{c}\text { ISSN 2525-4812 (versão online) } \\
\text { ISSN 2238-7641 (versão impressa) } \\
\text { http://www.revistaterceiramargem.com/ } \\
\text { index.php/terceiramargem/index }\end{array}$ & $\begin{array}{c}\text { Recebido em: 10/11/2020 } \\
\text { Aprovado em: 8/12/2020 } \\
\text { Período de publicação: jan., } 2021\end{array}$ & $\begin{array}{c}\text { Revista Terceira } \\
\text { Margem Amazônia } \\
(\text { v. } 6 \cdot \text { n. especial } 16 \cdot \text { Jan. } 2021)\end{array}$ \\
\hline
\end{tabular}

Como citar o artigo:

van LEEUWEN, J. ; GOMES, J. B. M. Promoting the cultivation of breadfruit in Amazonia. Revista Terceira Margem Amazônia, v. 6, n. especial 16, p. 209-217, 2021. DOI: http://dx.doi.org/10.36882/2525-4812.2021v6i16.ed.esp.p209-217

\title{
PROMOTING THE CULTIVATION OF BREADFRUIT IN AMAZONIA
}

\author{
Johannes van Leeuwea ${ }^{1}$ \\ João Batista Gomes ${ }^{2}$
}

\begin{abstract}
Summary: Breadnut (Artocarpus camansi, Moraceae) is known throughout Amazonia, but its clonal form, breadfruit (A. altilis), is not, although it has much more commercial potential. To facilitate the promotion of breadfruit, a simple form of vegetative propagation was developed, and nursery plants were distributed to promote this species. Bottomless PET-bottles showed useful in creating the humid environment needed for the rooting of breadfruit cuttings. It is important to insist with farmers that breadfruit is different from breadnut and needs more care. The developed mini-greenhouse substitutes a misting installation, does not depend on electricity or running water and can be used for rooting of cuttings and grafting of small quantities of woody species. Apoam's organic market in Manaus played an important role in the promotion of breadfruit's cultivation and commercialization. A self-service lunchroom was useful in the promotion of this food unknown in Manaus.
\end{abstract}

Keywords: vegetative propagation, cutting, mini-greenhouse, PET-bottle.

\section{PROMOVENDO O CULTIVO DA FRUTA-PÃO-DE-MASSA NA AMAZÔNIA}

Resumo: A fruta-pão-de-caroço (Artocarpus camansi, Moraceae) é conhecida em toda a Amazônia, mas sua forma clonal, a fruta-pão-de-massa (A. altilis), não, apesar de ter muito mais potencial comercial. Para facilitar a promoção da fruta-pão-de-massa foi desenvolvida uma forma simples de propagação vegetativa e mudas foram distribuídas para promover essa espécie. Garrafas PET sem fundo ajudaram a criar o ambiente úmido necessário para o enraizamento das estacas de fruta-pão-de-massa. É importante insistir com os agricultores que a fruta-pão-de-massa é diferente da fruta-pão-de-caroço e precisa de mais cuidados. A miniestufa desenvolvida substitui uma instalação de nebulização, não depende de eletricidade ou água corrente e pode servir para o enraizamento de estacas e enxertia de pequenas quantidades de espécies lenhosas. O mercado orgânico da Associação de Produtores Orgânicos do Amazonas (Apoam), em Manaus, desempenhou papel importante na promoção do cultivo e comercialização de fruta-pão-de-massa. Uma lanchonete do tipo self-service foi útil na divulgação dessa comida desconhecida em Manaus.

Palavras-chave: propagação vegetativa, estaca, miniestufa, garrafa PET.

\footnotetext{
1 MSc, Researcher National Research Institute of the Amazon (Inpa), Manaus, AM, Brazil.

(D) https://orcid.org/0000-0002-5423-0368

2 MSc, Researcher National Research Institute of the Amazon (Inpa), Manaus, AM, Brazil.

(D) https://orcid.org/0000-0001-8101-3468
} 


\section{Introduction}

Breadnut (Artocarpus camansi) (Figure $1 \mathrm{~A}$ and B) and breadfruit (A. altilis) (Figure $1 \mathrm{C}$ and D), a group of seedless, clonal forms of breadnut, are two taxa from the Pacific region, cultivated today in the humid tropics of all continents. Textbooks dedicate more attention to breadfruit because of its commercial importance. This can be verified in Brazil's coastal Northeast, where breadfruit and breadnut are both grown, but the occurrence and consumption of breadfruit are many times larger than those of breadnut.

Figura 1. Breadnut, non-ripe fruit (A) and mature fruit dropped to the ground, nuts envelopped in husks visible (B). Breadfruit, ready for harvest (C) and cut open, showing stalk and seedless mass of starch (D).
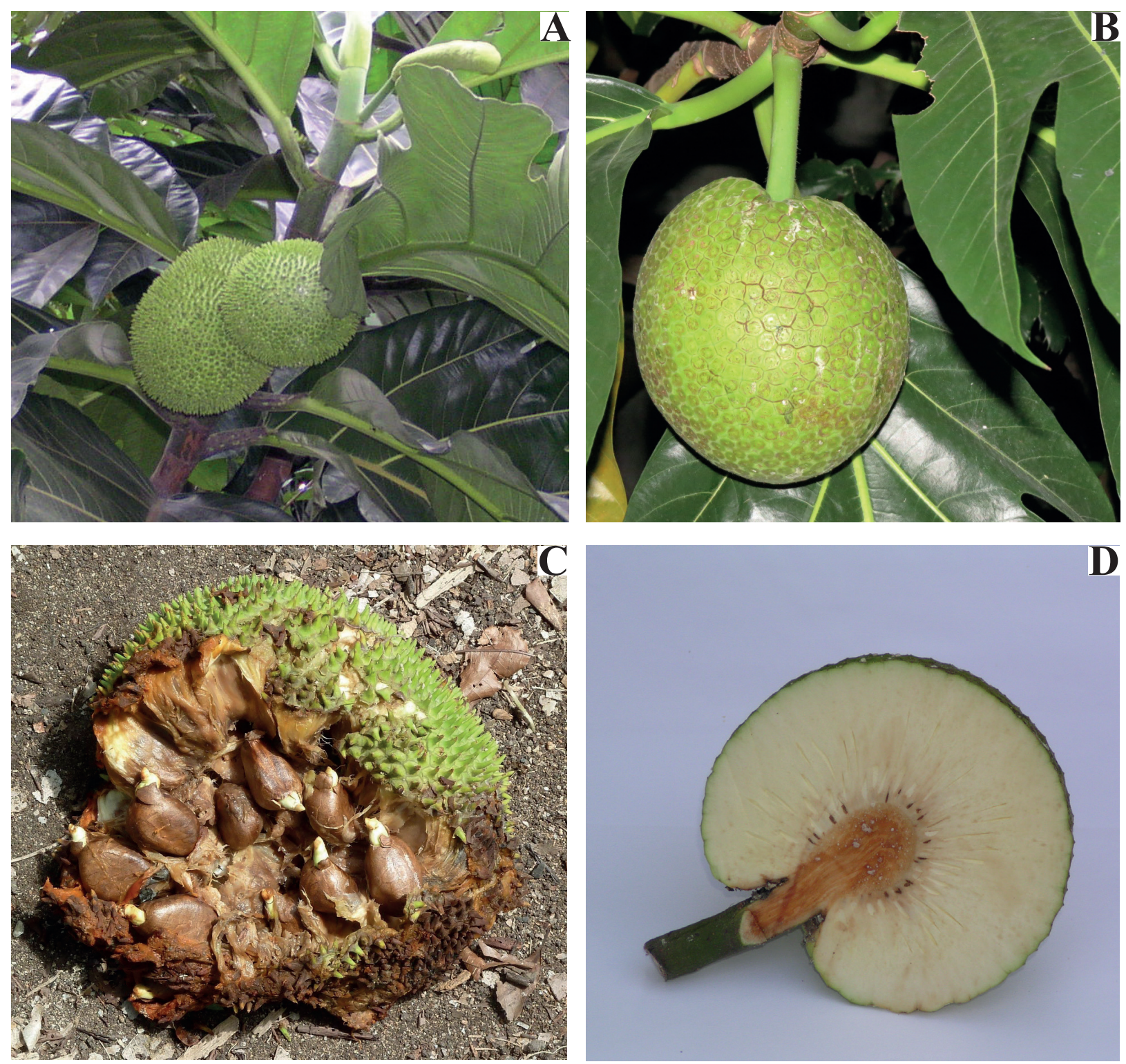
Despite its higher nutritional value (RAGONE, 1997), breadnut is less attractive for consumption, as the husks, enclosing the small "nuts" (Figure $1 \mathrm{~B}$ ), must be removed by hand, a time-consuming affair. Breadfruit on the contrary is a very versatile, easy to process type of food. Its 1-3 kg weighing, seedless, carbohydrate-rich, spherical fruit can be prepared in several ways and, if needed, in little time, while it also is a welcome component of a series of dishes. Containing more protein, breadfruit's nutritional value is comparable to that of starch crops like sweet potato and banana and better than that of cassava (RAGONE, 1997). Breadfruit has a distinctive, pleasant, non-dominant, "nutty" flavor (GOEBEL, 2004), which combines very well with other aromas.

Nevertheless, breadnut occurs throughout the Amazon, while breadfruit is virtually unknown in large parts of the region. This is caused by breadfruit's more difficult way of multiplication. For breadnut, a seed brought from elsewhere is sufficient for its introduction, while the vegetative multiplication of breadfruit needs special effort. Breadfruit cuttings are taken from root shoots. Root formation on cuttings only occurs in a humid environment, like that created by a misting installation or the frequent careful watering and covering of multiplication bins with plastic (ROBERTS-NKRUMAH, 2012).

Since breadfruit furnishes an excellent food, the tree is worth to be promoted in areas of the humid tropics where it is not yet well known. In such places the problem is how to produce small quantities of nursery plants of breadfruit in a cheap, not labor-intensive way. That would be helpful in an area like the state of Amazonas, where the demand for breadfruit nursery plants still must be created.

Research was done to find an easier way of vegetative multiplication and obtained nursery plants were distributed to gain experience with the promotion of this species and its adaptation to the region.

\section{PET-bottles to create a humid environment for the rooting of cuttings}

To create the humid environment needed for the rooting of cuttings, at first the cuttings were covered with plastic bags, but bottomless PET-bottles proved to be more practical. The PET-bottles were placed on pots with soil in which a cutting was planted. After placing the bottle around the cutting, it was pressed somewhat to make the bottle rim enter the pot's soil in order to limit interchange with the air outside the bottle. The planting pot with PET-bottle and cutting was placed in a shallow saucer filled with water to allow the pot's soil to absorb as much water as possible.

Two-liter and 5-liter PET-bottles were used. When the cuttings were too high for one bottle, two bottles of the same size were combined (Figure 2). Of a second bottle, both, bottom and bottleneck, were removed to obtain a tube. Four vertical cuts in the remaining tube allowed for a perfect fit of the two bottles. The hardening off of rooted cuttings occurred stepwise: loosening or taking away the cap of the bottle for periods of some hours up to an entire day. When the cutting did no longer need the presence of the cap of the bottle, the process was followed by taking away and replacing the entire PET-bottle. Once the bottle was no longer necessary, the new plant was gradually accustomed to full daylight. To avoid the deformation of the 2-liter bottles during sto- 
Figura 2. Breadfruit cuttings in mini-greenhouses made of PET-bottles. A mini-greenhouse using: two 5-liter bottles (left); two 2-liter bottles (center); one 2-liter bottle (right).

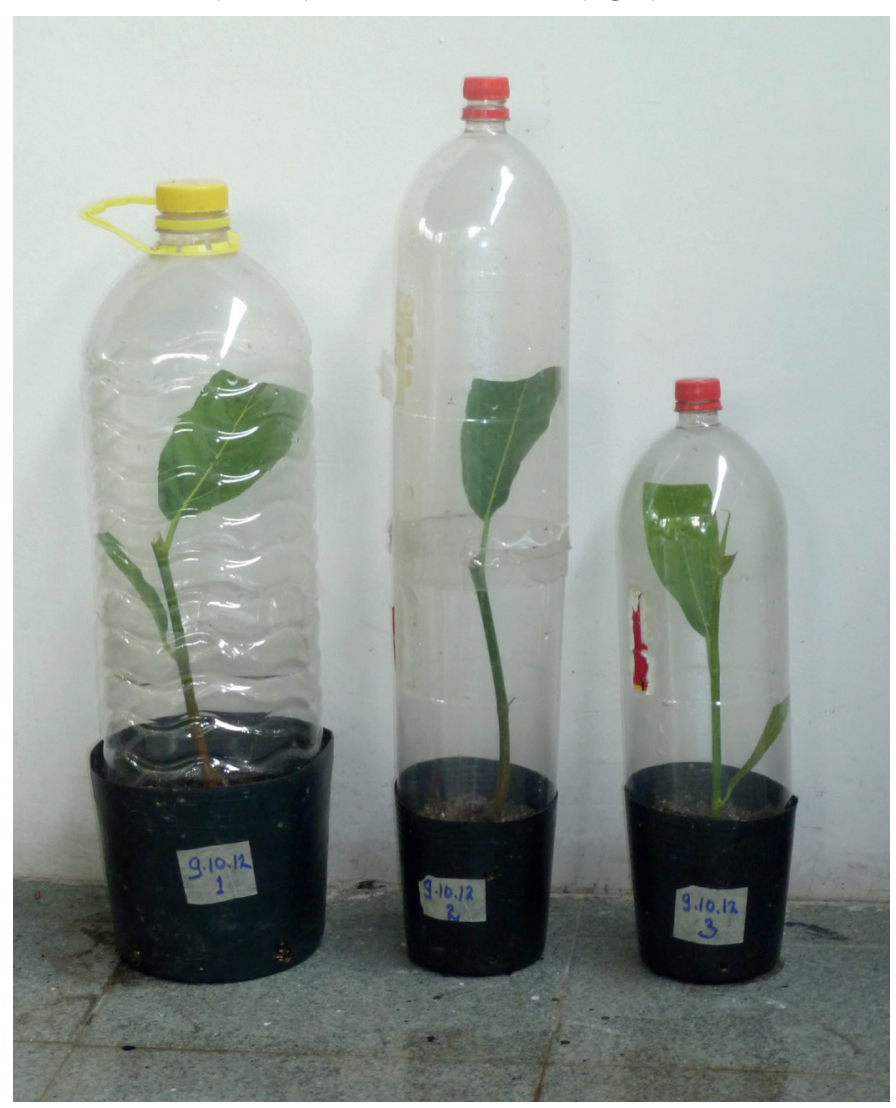

rage, the removed bottoms were placed in a reverse position in the underside of those bottles.

Cuttings were taken from spontaneous and provoked root shoots (cuts in a root close to the soil surface provoke root shoot formation). We used cuttings from 8 to $60 \mathrm{~cm}$ long with a base diameter from 3 to $12 \mathrm{~mm}$ and eliminated leaves on that part of the cutting, which was to be covered by soil. The persisting leaves of the cutting were partially pruned to obtain a remaining leaf area of around $50 \mathrm{~cm} 2$ per cutting (JAENICKE; BENIEST, 2002). A still expanding or recently formed top leaf was removed, but an eventual top bud maintained, as it can stimulate root formation (HARTMANN et al., 1997). Out-sticking parts of the leaves were trimmed to facilitate placing the bottle around the cutting.

The combination of planting pot and bottomless PET-bottle proved to create a good environment for the promotion of root development of breadfruit cuttings. Condensation drops appeared on the bottle's inside showing the higher humidity in the bottle. Cuttings placed in these mini-greenhouses for a month, eventually a few days more, rooted well, while irrigation in this period did not show to be necessary. The pot with cutting and PET-bottle cover should be in a well-lit location. Direct sun is only acceptable in the early morning, sun later the day can kill the cutting.

Part of the cuttings came from a single root shoot; others were obtained by dividing a root shoot in several cuttings. We had success with cuttings of all used sizes (6 to $60 \mathrm{~cm}$ ), but ended up preferring not too lengthy cuttings $(\leq 30 \mathrm{~cm})$ in order to have more cuttings. The capacity for rooting depends on the original distance above soil level of the base of the cutting. When the cutting's base is from a too high part of the shoot, it will not root. This aspect was not pursued, but cuttings with a base up to $45 \mathrm{~cm}$ above soil level rooted well.

Cuttings with a brown stem or stem base gave a rooting success of $78 \%$, those with a green base only 54\%. The difference was tested with a Chi square test and showed to be significant ( $\mathrm{p}$ $=0.03$ ).

The 2-liter bottles were used for one or two cuttings and the 5-liter bottle for up to seven cuttings. After a month, the cuttings in planting pots with more than one cutting were taken apart 
and the rooted plants were placed in individual pots, each with a 2-liter bottle protecting it for a short period.

\section{Distributing seedlings of a new variety that farmers think they already know}

The produced planting material was distributed. To facilitate its introduction, two types of leaflets were prepared: one for the general public and the future owner of a breadfruit tree, explaining how to plant and care for it and how to prepare the fruit and one with recipes for buyers of the fruit ${ }^{3}$. In several leaflets the difference with breadnut was explained.

The experiences with the distributed trees showed that breadfruit needs plenty of water and nutrients. In the first years after planting, a dry summer can kill the tree. Fortunately, it is easy to see if the young plant needs water: leafs loose turgor and start bending (Figure 3).

Figura 3. Breadfruit plant with lack of water (left) and same plant after adequate watering (right).
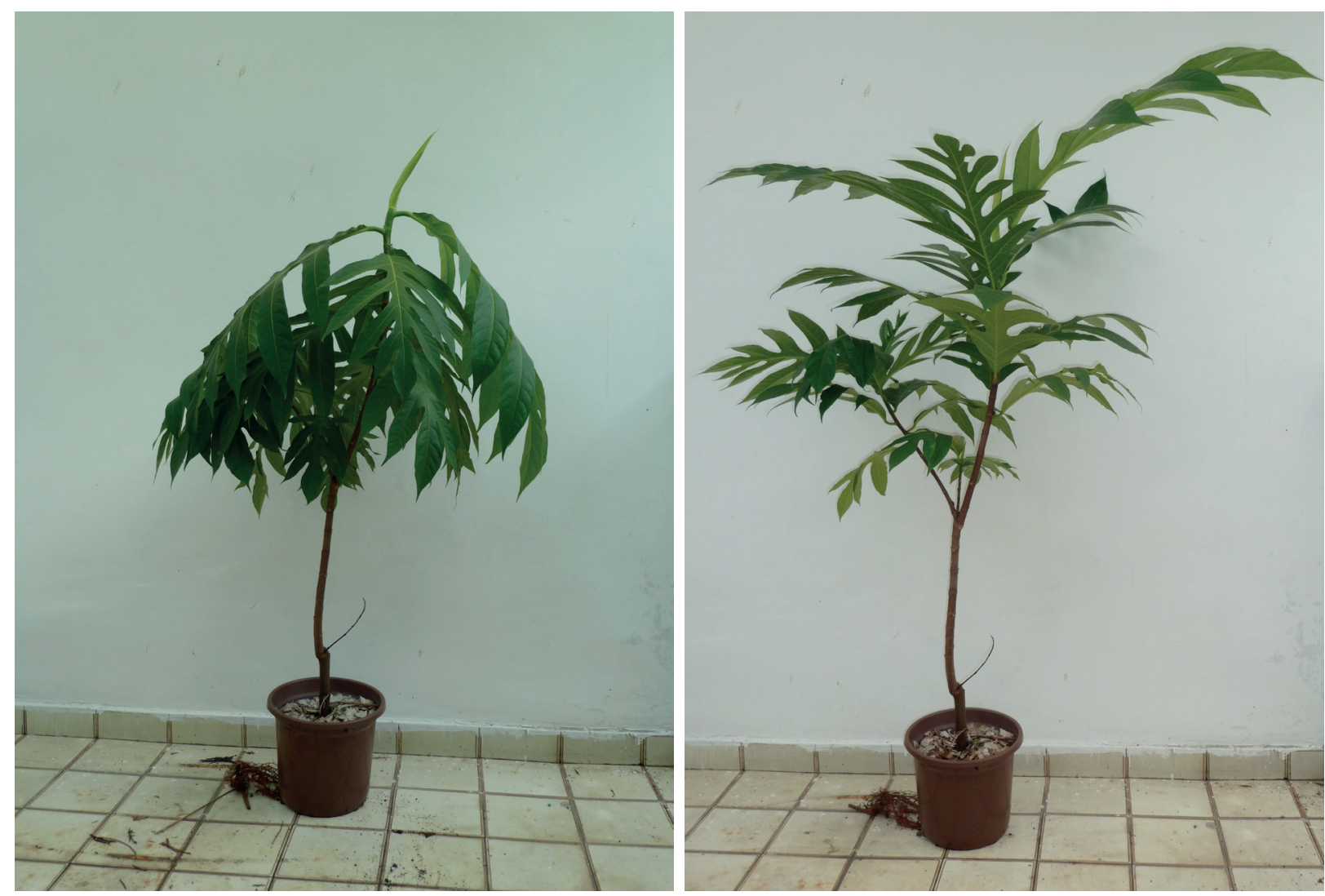

It is mistaken to plant the tree just somewhere in a field, as most of Amazon's upland soil is too poor in nutrients for this species (Figure 4 left). To avoid this, we explained this aspect and asked to see where it was going to be planted. If the indicated spot did not convince, no plant was given. Breadfruit is typically a backyard tree, where it can profit from water and receive household refuse as a form of fertilization. In Amazonia, many peasant farms have the toilet outside the house (OLIVEIRA et al., 2020, Figure 3). Planting the tree close to such a bathroom gave good results.

\footnotetext{
(https://www.dropbox.com/sh/emofunnlo9kj6sd/AACNZR755CwgNZys1Lp2H0Gsa?dl=0).
} 
Being a large tree with strong roots, it should not be too close to the house, as its roots may affect its structure (GOEBEL, 2004). To avoid accidents, it should also be in a place where people do not often circulate (a heavy fruit might drop suddenly, even on a windless day). Particularly good results occurred with trees planted close to horticultural fields. The neighboring tree clearly profited from the irrigation and fertilization occurring there. Planting in Indian Black Earth also gave good results (Figure 4 right).

Figura 4. Breadfruit tree on soil poor in nutrients (left) and breadfruit tree on Indian Black Earth (right).
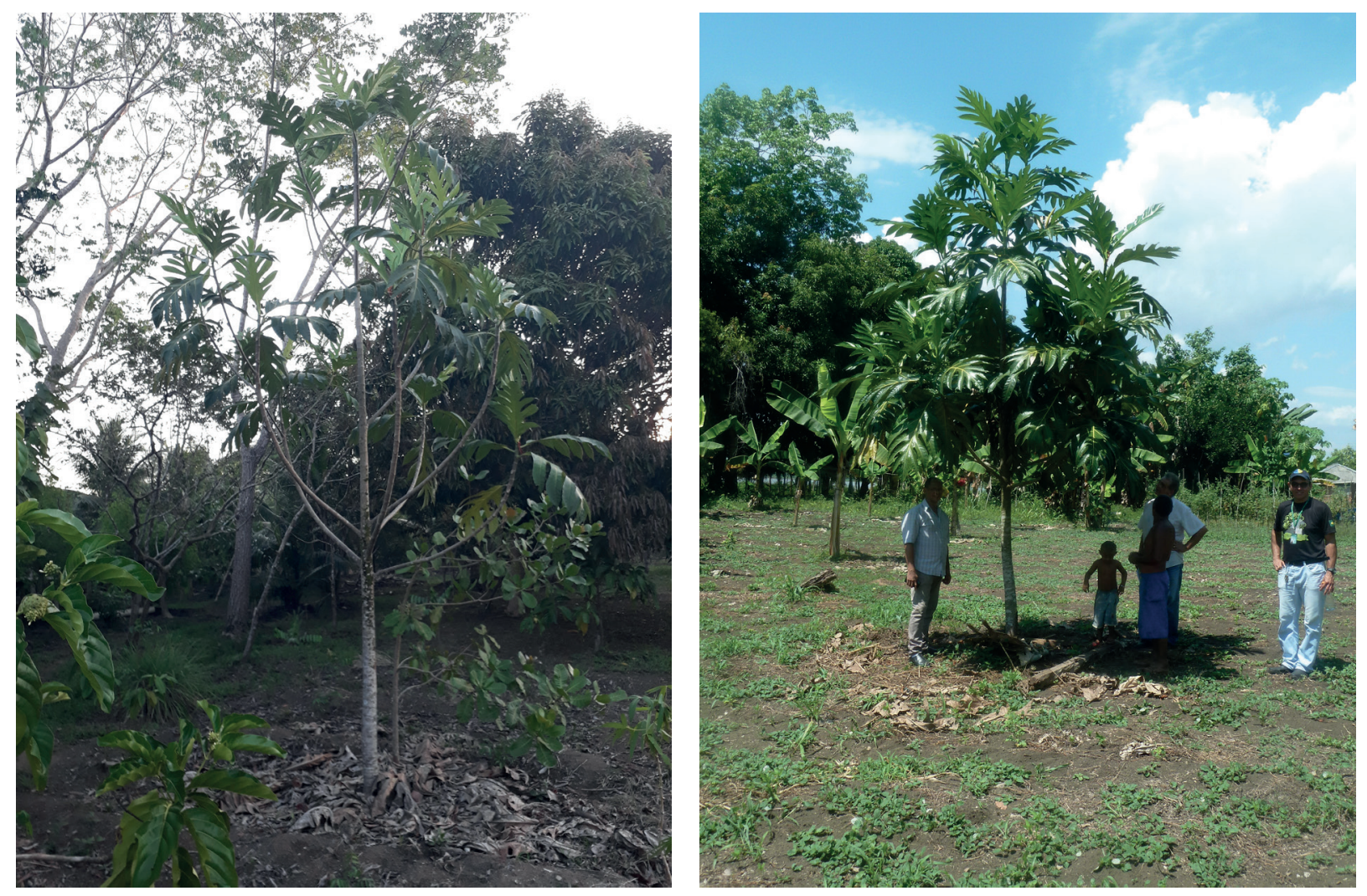

Convincing people to plant an unknown variety is not that easy. As the nursery plant was being offered for free, many people showed interest in obtaining one in a convincing manner (peasant farmers are often good 'actors'). Unfortunately, that does not always mean that the given plant will get the necessary care, essential during the first two years after planting. It can also happen that the person who receives the plant will pass it to somebody else of the household to plant and care for it. The accompanying leaflets were not always used and often disappeared.

In the case of breadfruit there is still another problem. Breadfruit and breadnut trees are visually remarkably similar, even the fruits on the trees of both species look the same, at least at first sight. Explaining aspects of a tree that farmers think they already know, is a difficult affair. Consequently, the famer who received a breadfruit nursery plant might forget the given details and treat the tree as if it was a breadnut.

This leads to two undesirable situations. The owner of a breadfruit tree will wait until the fruit falls to the ground and then finds to his or her surprise, instead of nuts, an open fruit containing a light yellow pulp and a smell that most people find unpleasant. The new tree might also not 
get sufficient care, as a breadnut tree is easily replaced, but a breadfruit tree should be considered an asset. Therefore, when the first fruits could be expected we revisited - as far as possible - the farmers who had received a breadfruit nursery plant, to find out how the harvest occurred and if and how the fruit was prepared.

The young tree grows well under some shade, but once in production, shade reduces the yield. The breadfruit is harvested when the fruit is still firm and not completely ripe (Figure $1 \mathrm{C}$ and D). This means that it must be taken from the tree, not collected under it. Consequently, keeping the tree lower turns harvesting easier. Breadnut is different in this aspect: nuts are collected after fruits drop to the ground (Figure $1 \mathrm{~B}$ ).

\section{Promoting breadfruit with the help of Apoam's market in Manaus and a lun- chroom using self-service}

Some eighty breadfruit plants were distributed. As a result, the fruit is now for sale in Manaus, while in six other municipalities producing breadfruit trees can be encountered.

The exceptionally small market of the Association of Organic Producers of Amazonas State (Apoam) at the Manaus' office of the Ministry of Agriculture (ERAZO, 2018; BATISTA et al., 2019) showed to be of great help in the promotion of breadfruit. Some of the organic farmers of that market received breadfruit nursery plants, resulting some years later in breadfruit being sold here.

The public of the Apoam's market is quite different from the average Manaus' customer: most have higher education and an income above $\mathrm{R} \$ 3,000.00$ / month (ERAZO, 2018). The public is also 'select' in the sense that it spends time and effort to visit this market, what distinguishes them from the far-out majority of Manaus' inhabitants with the same income and education. What makes this public singular is their interest in procuring to know better forms of alimentation. This not in the sense of widening their culinary or gastronomical horizon, but as a genuine pursuit of knowledge vital for the health of the consumer, farmer and planet. Food sustainably produced by a tree cultivated by an organic farmer of course enters in the sought type of alimentation.

Most visitors of the Apoam's market had never seen or even heard about breadfruit. Nevertheless, several among the market visitors bought fresh breadfruits and took leaflets home with instructions for preparation. There appeared even interest in buying nursery plants of breadfruit, but this interest was not sustained.

In 2018, a farmer, not related to Apoam, started selling fresh breadfruit in his Manaus' shop and in prepared form in the lunchroom, part of that shop. The sale of fresh breadfruit did not last, but he continues to sell fried and boiled breadfruit and dry chips. Especially the fried form sells very well.

At the small Apoam's market, the price for the breadfruit has already diminished substantially. Selling it in fresh form at other markets will be much more difficult: the normal market public has no time for 'difficult', time-consuming novelties. Fruits for fresh consumption with an attractive color can be relatively easy to promote. The case of breadfruit is different: a large greenish ball of starch (Figure $1 \mathrm{C}$ and $\mathrm{D}$ ) to be boiled or fried to turn it ready for consumption. 
Contacting other self-service restaurants and lunchrooms to suggest adding breadfruit as one more option seems the way out. In self-service, customers themselves chose the components of what they are going to eat. Knowing and trusting the place, they might venture to include a small part of something new. If they like the experience, a new client might be won. Sooner or later, someone among those clients may wish to know more about that new food.

\section{Conclusion}

The presented production form of a limited quantity of breadfruit nursery plants is of interest, as it does not need a misting installation, nor does it depend on electricity or running water (which can have interruptions) and needs little labor. The described method can be of interest for nurseries in areas where breadfruit is not yet well known. A nursery could buy a nursery plant (offered on the Internet for $\mathrm{R} \$ 60$ to $\mathrm{R} \$ 120$ a plant) and plant it nearby in a convenient place. Once the tree is well established, reproduction can start.

The mini-greenhouse (bottomless PET-bottle covering a planting pot) avoids the drying out and leaching of cuttings and scions of newly made grafts. This characteristic makes it attractive for nurseries interested in the vegetative propagation of small quantities of coffee, cacao, fruit trees and ornamental plants.

Apoam's organic market in Manaus played an important role in the encouragement of breadfruit's cultivation and commercialization. Self-service lunchrooms and restaurants can be of help to promote the consumption of breadfruit in areas where it is not well-known.

\section{References}

BATISTA, S. C. P.; COSTA, S. C. F. C.; COSTA, F. S.; BONATTO, E. C. S. Frutas e hortaliças orgânicas comercializados na feira da Apoam (Associação dos Produtores Orgânicos do Amazonas) de ManausAM. Revista Terceira Margem Amazônia, v. 4, n. 12, Jan./Jun. 2019. Available at: http://www.revistaterceiramargem.com/index.php/terceiramargem/article/view/263/194. Accessed on: 11 nov. 2020.

ERAZO, R. L. Mercado de alimentos orgânicos e a agrobiodiversidade em Manaus, AM. Revista Terceira Margem Amazônia, v. 3, n. 11, p. 237-245, 2018. Available at: http://www.revistaterceiramargem.com/ index.php/terceiramargem/article/view/245/183. Accessed on: 11 nov. 2020.

GOEBEL, R. Breadfruit. Peninsula Garden Note. Cape York, 5 p. 2004. Available at: http://plant.daleysfruit.com.au/l/breadfruit-tress-677.pdf. Accessed on: 12 jan. 2020.

HARTMANN, H. T.; KESTER, D. E.; DAVIES, F. T.; GENEVE, R. L. Plant propagation, principles and practices. 6. ed. New Jersey: Prentice-Hall, 1997. 770 p.

JAENICKE, H.; BENIEST, J. Vegetative tree propagation in agroforestry. Nairobi: Icraf, 2002. 133 p.

OLIVEIRA, K. R. A.; BERNARDES, C.; BERNARDES, R. S. Tecnologias sociais de acesso à água em comunidades extrativistas: um longo processo para garantia de um direito humano. Revista Terceira Margem Amazônia, v. 6, n. 14, p. 63-78, 2020. Available at: http://dx.doi.org/10.36882/2525-4812. 2020v6i14p63-78. Accessed on: 09 nov. 2020. 
RAGONE, D. Breadfruit Artocarpus altilis (Parkinson) Fosberg. Rome: Ipgri, 1997. 77 p. Available at: https://www.bioversityinternational.org/fileadmin/_migrated/uploads/tx_news/Breadfruit_Artocarpus_ altilis_Parkinson_Fosberg_342.pdf. Accessed on: 26 oct. 2020.

ROBERTS-NKRUMAH, L. B. Breadnut and breadfruit multiplication, a manual for commercial propagation. Rome: FAO, 2012. 20 p. Available at: http://www.fao.org/3/a-i3085e.pdf. Accessed on: 26 oct. 2020. 
